\title{
Psychological Changes During Puberty - Adolescent School Girls
}

\author{
M. Reena \\ Department of Population Studies, Sri Venkateswara University, Tirupati
}

Copyright $@ 2015$ Horizon Research Publishing All rights reserved.

\begin{abstract}
Adolescence is a period when physical growth and maturation are accompanied by mental and psychological development. Pubertal timing was associated with different symptoms than pubertal status or age. Puberty seems to affect girls more negatively than boys. Stage of pubertal development rather than chronological age has been reported as a risk factor for eating disorders, depression and anxiety. Many mental disorders such as major depression certain anxiety disorders, eating disorders, and substance use disorders increase in prevalence during adolescence. Puberty includes major hormonal changes that are likely to contribute for example to both depressive affect and aggression. WHO estimate shows that up to 20 per cent adolescent have one or more mental or behavioural problems. Studies conducted in different parts of the world show that prevalence of behavioural and emotional problems in adolescents ranges from 16.5 per cent to 40.8 per cent and in India it is in the range of 13.7 per cent to 50 per cent as adolescents form one fifth of India's population. The study set out to assess the relationship between pubertal timing and emotional and behavioural problems in middle adolescence. Physical as well as psychological changes during adolescence create a state of physiological stress that must be coped with. The study involved a school based survey of health, health behaviour and behaviour in school as well as questions about emotional and behavioural problems, the association between socio-environmental factors was also examined.
\end{abstract}

Keywords Puberty, Mental Illness, Emotional, Behavioural Problems, Adolescence

\section{Introduction}

Adolescence is a time of big social and emotional development for children. During adolescence women notice a host of changes in the manner child interacts with family, friends and peers. Every child's social and emotional development is different. Child's development is shaped by child's unique combination of genes, brain development, and environment, experiences with family friends, community and culture. Social and emotional changes show that child is forming an independent identity and learning to be an adult. People spend their childhood learning to be like their parents, and their adolescence learning who they are and how they are different from their parents (raising Children Network).

In humans puberty coincides with physical growth and brain maturational changes and also with emotional, cognitive and behavioural changes. The transition from childhood to adulthood occurs during adolescence period which is characterized by major biological changes like physical growth, sexual maturation and psycho-social development. The age of attaining sexual maturity among a girl, when she changes physically, hormonally and sexually has dipped, especially in urban India, to 10 years from 12-13 earlier, not just in India but globally (The Times India, 2012). During this phase growth the girls first experience is menstruation and related problems which is marked by feelings of anxiety and eagerness to know about this natural phenomenon. Menarche is the first menstrual period or first menstrual bleeding. It is the most commonly remembered puberty for most women that occurs during the period of adolescence.

The most common explanations for the effect of pubertal timing on depressive symptoms imply a psychosocial relationship precipitated by the physical changes associated with puberty. Girls who exhibit obvious signs of physical maturation may find it difficult to maintain friendships with same-sex peers who have not developed at a similar rate (Petersen et al., 1991). It is important to note that, in the case of depressive symptoms, a psychosocial model is not necessarily inconsistent with a biological one. It is possible that hormonal changes or levels may intensify negative, emotional responses to environmental and circumstances. Alternatively, hormonal shifts may affect girls' behaviour in a way that directly influences interactions with peers, parents, boys, or others. This is in turn, results in perplexing or distressing social consequences that impact psychological well-being Jane (Mendle et al, 2006).

Puberty is a time of increasing stresses and challenges, as children adapt to their changing social roles. For this reason, mental health issues often first emerge in adolescence. Younger children and those with fewer social and emotional 
resources may find this phase more difficult, which increases their risk of subsequent mental health difficulties. Social determinants and health-related behaviours are also highly influential. The families, peers and communities children grow up with can provide social scaffolds for their mental health. Equally, negative influences in children environment can be risk factors for mental health difficulties in adolescence. Girls who reached puberty early also had more difficulties in emotional and social adjustment from early childhood.

\section{Puberty and Mental Illness}

Many mental disorders such as major depression (Angold, Costello, \&Worthman, 1998), certain anxiety disorders (Feehan, McGee, Raja, \& Williams, 1994; Hayward et al., 1992), eating disorders (Steinhausen, 1994) and substance use disorders (Perkonigg, Lieb, \&Wittchen, 1998) increase in prevalence during adolescence. A total of $15-25 \%$ of adolescents meets the diagnostic criteria of some specific mental disorder (Newman et al., 1996). Stage of pubertal development rather than chronological age has been reported as a risk factor for eating disorders (Koff\&Rierdan, 1993), depression (Angold et al., 1998) and anxiety (Hayward et al., 1992). Puberty includes major hormonal changes that are likely to contribute for example to both to depressive affect and aggression.

Puberty is a time of increasing stresses and challenges, as children adapt to their changing social roles. For this reason, mental health issues often first emerge in adolescence. Younger children and those with fewer social and emotional resources may find this phase more difficult, which increases their risk of subsequent mental health difficulties.

Adolescents are those between the ages of 10 and 19 years. Adolescence is a period when physical growth and maturation are accompanied by mental and psychological development. This period needs special attention because of the turmoil. An adolescent faces due to different stages of development, different circumstances, different needs, and diverse problems. Thus, United Nations Children's Fund (UNICEF) and United Nation Fund for Population Activities (UNFPA) joined World Health Organization (WHO) and issued a joint statement on reproductive health of adolescents in 1989 to address to their problems.

\section{Materials and Methodology}

The study was undertaken to study the puberty as related to psychological problems during adolescence among school going girls. The present study was carried out among school-going adolescent girls in Chittoor district from July 2014 to August 2014. Optimum sample sizes of 157 school-going adolescent girls of district, aged 10-15 years were selected, and the selected girls were interviewed. Multi-stage random sampling technique was used to select the requisite number of eligible girls. Tirupati revenue division was selected for data collection. In Tirupati division three high schools in urban and two from rural area were selected for the study. At the second stage, students from classes VI to IX of age group 10-15 years were selected. Students within the class were selected through systematic random sampling. A structured interview schedule was developed and interview was conducted on adolescent girls of a school other than the ones selected for the study. A separate room in each school was used for interview. The girls were interviewed separately and privately. The menstrual history was inquired; the exact date of menarche was noted.

\section{Data Analysis}

Data were entered in SPSS and analyzed with SPSS Version 16.0.

\section{Results}

In all of 157 school girls from class VI-IIX of at Tirupati were participated. All participants are responded to all items in the schedule. The analysis is therefore presented as percentage of respondents to that particular item on the schedule. Item wise responses are summarized in table. Table-1 indicates the socio economic status of the respondents, in this table percentage was distributed for the respondent's age, class religion and annual income of the family.

Table 1. Socio-economic characteristics of the respondents $(\mathrm{N}=157)$

\begin{tabular}{|c|c|c|c|}
\hline S.No & Socio-economic characteristics & Frequency & Percent \\
\hline \multirow{5}{*}{1} & \multicolumn{3}{|l|}{ Age } \\
\hline & 12 & 26 & 16.6 \\
\hline & 13 & 56 & 35.7 \\
\hline & 14 & 65 & 41.4 \\
\hline & 15 & 10 & 6.4 \\
\hline \multirow{4}{*}{2} & \multicolumn{3}{|c|}{ Class } \\
\hline & 7 & 52 & 33.1 \\
\hline & 8 & 55 & 35 \\
\hline & 9 & 50 & 31.8 \\
\hline \multirow{4}{*}{3} & \multicolumn{3}{|c|}{ Religion } \\
\hline & Hindu & 145 & 92.4 \\
\hline & Muslim & 6 & 3.8 \\
\hline & Christian & 6 & 3.8 \\
\hline \multirow{3}{*}{4} & \multicolumn{3}{|c|}{ Family income } \\
\hline & $\leq 1,00,000$ & 107 & 67.2 \\
\hline & $\geq 1,00,000$ & 50 & 31.8 \\
\hline
\end{tabular}

In table presents emotional/behavioural problems among school girls during puberty. In some questions on related to 
bahaviour of girls routine lifestyle. Such as was categorized as loss of sleep, feeling more sensitively. Majority of the girls 36.3 percent were have sufficient sleep to their body and 29.9 percent of the girls are postponing their sleep to weekends for the lack of sleep most of the girls (56.7 per cent) were facing irritation problems at the time of irritation their behavior was changing in different like breaking things (3.8 per cent) angry (36.9 per cent) beating other (13.4 per cent) cry (per cent) shouting with other (22.7 per cent) sleep (9.6 per cent). Because of these problems they did not concentrate their studies ( 35.7 per cent) lack of sleep is also one of the reason for their moodiness ( 24.8 per cent).

Table 2. Behavioural changes among school girls $(\mathrm{N}=157)$

\begin{tabular}{|c|c|c|c|}
\hline S.No & Behavioural changes & Frequency & percent \\
\hline I & \multicolumn{3}{|c|}{ Loss of Sleep } \\
\hline \multirow{7}{*}{1} & \multicolumn{3}{|c|}{ how many hours do you sleep } \\
\hline & 5 hours & 6 & 3.8 \\
\hline & 6 & 6 & 3.8 \\
\hline & 7 & 20 & 12.7 \\
\hline & 8 & 57 & 36.3 \\
\hline & 9 & 41 & 26.1 \\
\hline & 10 & 27 & 17.2 \\
\hline \multirow{4}{*}{2} & \multicolumn{3}{|c|}{ postpone sleep to weekends } \\
\hline & Don't know & 12 & 7.6 \\
\hline & No & 98 & 62.4 \\
\hline & Yes & 47 & 29.9 \\
\hline \multirow{4}{*}{3} & \multicolumn{3}{|c|}{ lack of sleep is cause for irritability } \\
\hline & Don't know & 6 & 3.8 \\
\hline & No & 62 & 39.5 \\
\hline & Yes & 89 & 56.7 \\
\hline \multirow{8}{*}{4} & \multicolumn{3}{|c|}{ At the time of irritation } \\
\hline & Breaking things & 6 & 3.8 \\
\hline & Angry & 58 & 36.9 \\
\hline & No & 11 & 7 \\
\hline & Beat to others & 21 & 13.4 \\
\hline & Cry & 11 & 7 \\
\hline & Soughting with others & 35 & 22.3 \\
\hline & Sleep & 15 & 9.6 \\
\hline \multirow{4}{*}{5} & \multicolumn{3}{|c|}{ Lack of concentration in work or task } \\
\hline & Don't know & 5 & 3.2 \\
\hline & No & 96 & 61.1 \\
\hline & Yes & 56 & 35.7 \\
\hline \multirow{4}{*}{6} & \multicolumn{3}{|c|}{ lack of sleep is one of the reason/cause for modiness } \\
\hline & Don't Known & 11 & 7 \\
\hline & No & 107 & 68.2 \\
\hline & Yes & 39 & 24.8 \\
\hline
\end{tabular}

Table-3 indicates the emotional problem among school girls ( 28 per cent) of the girls are responded that they have boys in their friends circle, the same per cent ( 28 per cent) of the girls expressed they were attracted by the people. 19.7 per cent of girls were did not aware what happening surroundings. The interesting point noted that 80.9 per cent of the girls did not discussing reproductive health matters with their mother and 73.2 per cent of the girls are taking their own decision in problem solving process.

Table 3. Emotional problems among school girls $(\mathrm{N}=157)$

\begin{tabular}{|c|c|c|c|}
\hline S.No & Emotional problems & Frequency & Percent \\
\hline I & Getting sexual feelings & & \\
\hline \multirow{3}{*}{1} & \multicolumn{3}{|c|}{ Do you have friends in boys? } \\
\hline & No & 113 & 72 \\
\hline & Yes & 44 & 28 \\
\hline \multirow{4}{*}{2} & \multicolumn{3}{|c|}{ Do you think that you are attracted by people? } \\
\hline & Don't know & 31 & 19.7 \\
\hline & No & 82 & 52.2 \\
\hline & Yes & 44 & 28 \\
\hline \multirow{4}{*}{3} & \multicolumn{3}{|c|}{ Do you attract with boys? } \\
\hline & Don't know & 22 & 14 \\
\hline & No & 117 & 74.5 \\
\hline & Yes & 18 & 11.5 \\
\hline \multirow{3}{*}{4} & \multicolumn{3}{|c|}{ Getting sexual feeling in everyday activities such as } \\
\hline & $\begin{array}{c}\text { Watching romantic scene on } \\
\text { Television }\end{array}$ & 6 & 3.8 \\
\hline & Don't Know & 151 & 96.2 \\
\hline \multirow{3}{*}{5} & \multicolumn{3}{|c|}{ Discussing sexual matters with your mother or elders } \\
\hline & No & 127 & 80.9 \\
\hline & Yes & 30 & 19.1 \\
\hline II & \multicolumn{3}{|c|}{ Feeling unce } \\
\hline \multirow{3}{*}{1} & \multicolumn{3}{|c|}{ Decision Making } \\
\hline & Taking own decision & 115 & 73.2 \\
\hline & Depending on others & 42 & 26.8 \\
\hline
\end{tabular}

\section{Discussion}

Early adolescence is the life phase of physical maturation, but also of other age-related psychological or socio-cultural developments. Each of these developments involves risks and opportunities, and may affect mental health problems. Furthermore, a physical development which is out of pace with same-aged peers may pose an additional challenge. In this present study, we examined which specific emotions and behaviors are associated with pubertal stage, taking into account chronological age and pubertal timing. Studies on psychosocial and psychiatrict problems among adolescents reveal this point. A clinic-social study of psychiatric morbidity among adolescent school going girls age 12-18 years of Delhi (2001) by Mishra et al, reveal that 13.76 per cent of girls had psychiatric morbidity, the commonest problem being anxiety/depression (10 per cent). They also 
found that the primary factors associated with psychiatric morbidity were linked to the girls relationship with parents, the another study that lack of awareness and correct information about psychological changes of adolescence by jain RB et al (2013).To the best of our knowledge, to address effects of pubertal status, age, and pubertal timing simultaneously with regard to a comprehensive set of mental health problems.

\section{Need for social work intervention}

There are numerous factors that affect the onset and progression of puberty, including genetic and biological influences, stressful life events, socioeconomic status, nutrition and diet, amount of body fat, and the presence of a chronic illness. There is need a help to parents and other adults about how to discuss puberty with younger adolescents. Research findings suggest that adolescent girls who are unprepared for the physical and emotional changes of puberty may have the most difficulty with menstruation. The mother can provide emotional support and assurance, emphasize the pragmatics of physical changes, and provide information about how it will actually feel, emphasizing positively their own first experiences with puberty. There is a need to organizing individual counseling and group work to create the awareness on psychological changes during puberty among school going adolescent girls.

\section{Conclusions}

Adolescent girls emerge to be in need for counseling and support for coping with the bodily as well as psychological changes of adolescence. A common policy is needed to implement and ensure counseling through imparting and incorporating education on psychological changes during puberty in all school Health Education Programmes are to be carried out especially in High Schools and Higher Secondary Schools.

\section{REFERENCES}

[1] Sharma P, Malhotra C, Taneja DK, Saha R. Problems related to menstruation amongst adolescent girls. Indian J Pediatr $2008 ; 75: 125-9$

[2] World Health Organ. Physical status: The use and interpretation of anthropometry. Report of the WHO Expert Committee. World Health Organ Tech Rep Ser 1995;854:1-452
[3] Sadhna G, Achala S. Awareness about reproduction and adolescent changes among school girls of different socioeconomic status. J ObstetGynecol India 2006;56:324-8.

[4] Social and emotional changes in adolescence by raising children network, with the centre for adolescent health

[5] Mishra A, Sharma AK. A clinico-social study of psychiatric morbidity in 12 to 18 years school going girls in urban Delhi. Indian J Comm Med. 2001;26:71-5.

[6] Jain RB, Kumar A, Khanna P. Assessment of self-awareness among rural adolescents: a cross-sectional study. Indian $\mathrm{J}$ EndocrinolMetab. 2013;17:S367-72.

[7] Hayward, C., Killen, J., Hammer, L., Litt, I. F., Wilson, D., Simmonds, B., \& Taylor, C. B. (1992). Pubertal stage and panic attack history in sixth- and seventh-grade girls. American Journal of Psychiatry, 149, 1239-1243.

[8] Feehan, M., McGee, R., Raja, S. N., \& Williams, N. J. (1994). DSM-III-disorders in New Zealand 18 year olds. Australian and New Zealand Journal of Psychiatry, 28, 87-99.

[9] Angold, A., Costello, E. J., \&Worthman, C. K. (1998). Puberty and depression: The roles of age, pubertal status and pubertal timing. Psychological Medicine, 28, 51-56.

[10] Steinhausen, H.-C. (1994). Anorexia and bulimia nervosa. In M. Rutter, E. Taylor, \& L. Hersov (Eds.), Child and adolescent psychiatry (3rd ed.). ) (pp. 425-440). Oxford: Blackwell.

[11] Perkonigg, A., Lieb, R., \&Wittchen, H. U. (1998). Prevalence of use, abuse and dependence of illicit drugs among adolescents and young adults in a community sample. European Addiction Research, 4, 58-66.

[12] Koff, E., \&Rierdan, J. (1993). Advanced pubertal development and eating disturbance in early maturating girls. Journal of Adolescent Health, 14, 433-439.

[13] Newman, D., Moffit, T.E Caspi,A., Magdol,L., Silva, P.A, \& Stanton, W. (1996). Psychiatric disorders in a birth cohort of young adults; Prevalence, combodity, clinical significance, and new case incidence form ages 11-21, Journal of consulting and Clinical Psychology, 64, 552-56

[14] Raising Children Network, with the Centre for Adolescent Health, Australian Parenting website, www.raisingchildren.net.au

[15] Jane Mendle, Eric Turkheimer, and Robert E. Emery Detrimental Psychological Outcomes Associated with Early Pubertal Timing in Adolescent Girls, Dev Rev. Jun 2007; 27(2): 151-171.

[16] Petersen AC, Sarigiani PA, Kennedy RE. Adolescent depression: why more girls than boys? Journal of Youth and Adolescence. 1991;20:191-215.

[17] Kounteya Sinha, Now, girls hit puberty at 10, April 26, 2012, The Times of India. 